\title{
TOWARDS CREATIVE CITY. CASE STUDY OF KATOWICE
}

DOI: http://dx.doi.org/10.18509/GBP.2018.36

UDC: $911.375(438)$

\section{Wojciech Koman}

\section{Elżbieta Zuzańska-Żyśko}

Department of Economic Geography, Faculty of Earth Sciences, University of Silesia, Poland

\begin{abstract}
Katowice is one of the cities of Górnośląsko-Zagłębiowska Metropolis which develops metropolitan functions. Music and accompanying events of supraregional, national and international reach play a significant role in the urban space of the city. Some researchers perceive new creative services of a higher order, typical for a metropolis, in this activity. It combines the elements of traditional cultural function and creative industry. The purpose of the article is the description of actions aiming at the development of a metropolitan function based on culture, music in particular, in the city of Katowice. The purpose of the article is attracting attention to the formation of new metropolitan space and specialized metropolitan function in Katowice. This centre is one of the first City of Music in Central and Eastern Europe which at the same time belongs to the UNESCO Network of Creative Cities.
\end{abstract}

Key words: creative city, culture, metropolitan area, city of the music, Poland

\section{INTRODUCTION}

Creativity becomes one on the most desired features of cities in the twenty-first century. Katowice is one of the cities of Górnośląsko-Zagłębiowska Metropolis which has systematically and for some time now been developing metropolitan functions. More and more attention is paid by the city to music, both in the sphere of culture, as well as modern urban space which is the background for various types of music events. Music has become a certain type of innovation in the business activity of a city. Numerous researchers, including geographers, see the development of high-order services typical for a metropolis here. On one hand creative elements concreate traditional cultural functions, on the other they contribute to the development of creative industries. Many studies highlight that the occurrence of metropolitan functions, including the ones in culture, is a significant criterion of the identification of a metropolis [9], [14], [15], [18]. Some researchers underscore the relations thereof with a symbolic function [2], [22], [23], understood not only in the light of culture and entertainment, but also as an identification with monumental post-industrial objects, world-class spatial projects, as well as the institutions of culture, art and creative tourism created on this basis [4]. Obviously, art attracts creative and talented individuals, which translates into the economy and economic development of a city [6]. It also influences the identification of cities, which develop their brands.

\section{METHODOLOGY AND STUDY AREA}

This study analyses the case of Katowice located in the south of Poland (Figure 1). This centre is not big in terms of population, with the total of 290 thousand inhabitants (2016), 
nevertheless is has a high rank in the settlement hierarchy, as a centre of big and complex urban system of Upper-Silesian conurbation which in 2017 became a lawful and legal metropolitan centre under the name of Górnośląsko-Zagłębiowska Metropolis. Simultaneously, it is the capital of Silesia, the most urbanized region in Poland, where $78 \%$ of population reside in cities.

The purpose of the article is the description of actions aiming at the development of a metropolitan function based on culture, music in particular, in the city of Katowice. It combines the elements of traditional cultural function and creative industry. Katowice is a member of the Network of Creative Cities of UNESCO which connects several centres: six in Europe (Bologna, Gandawa, Glasgow, Hannover, Mannheim and Seville) and three on other continents (Bogota in Colombia, Hamamatsu in Japan and Brazzaville in Congo). It is the first City of Music in East-Central Europe and the second after Kraków City of Literature.

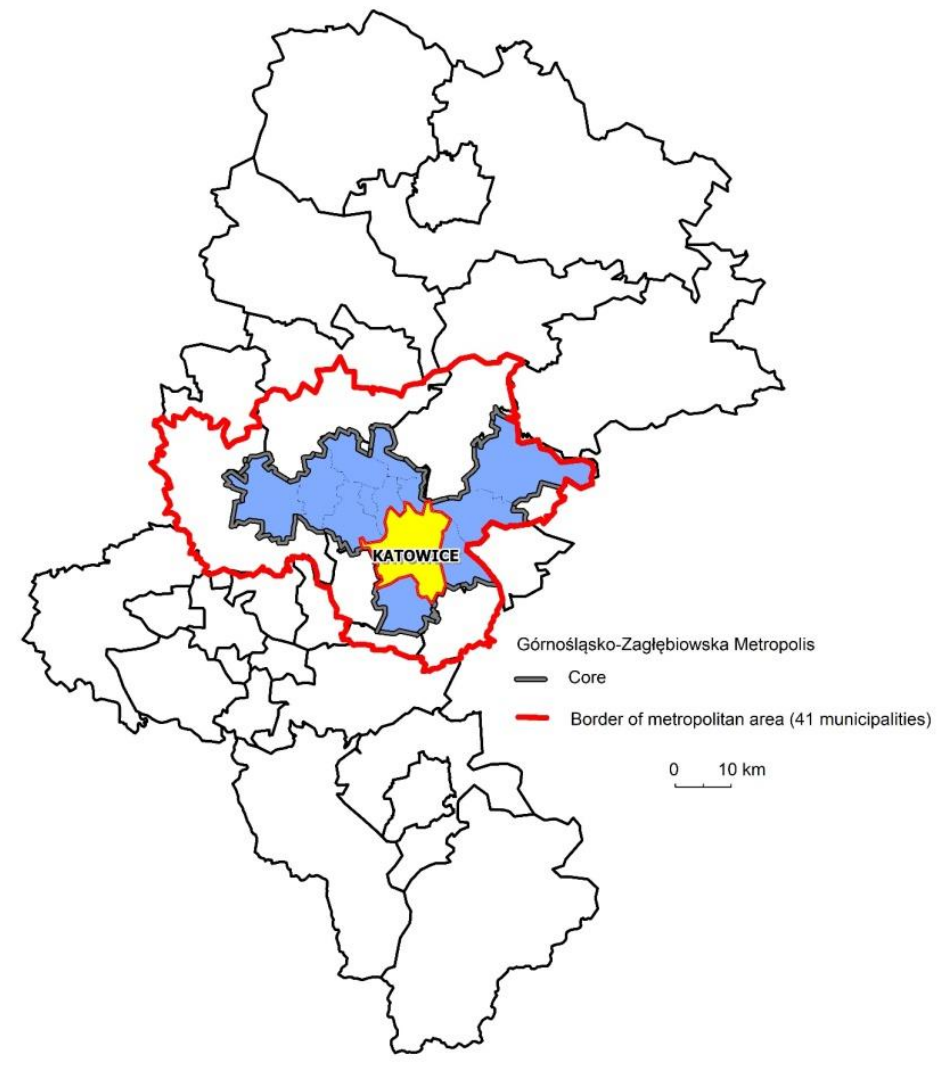

Figure 1. The location of Katowice in the Górnośląsko-Zagłębiowska Metropolis in relation to Silesia in 2017

Source: author's elaboration.

The article utilizes the data in terms of culture in Katowice, encompassing 2011-2016, which originate both from the national statistics of GUS (General Statistics Office; www.stat.gov.pl), NSP 2011, as well as various cultural institutions. What is more, databases concerning cultural institutions from the City Council of Katowice were used, supplemented with information from cultural portals. The analysis of material was carried out in the light of the usage of cultural space, as well as cultural institutions located thereon, taking into consideration - in particular - the data concerning cultural events organized and the number of participants thereof. 


\section{CREATIVE CITY. THEORETICAL ASPECT}

In cities specified as creative, broadly understood creative activities are considered the essence. Apart from activities saturated with knowledge, they are a component of the creative sector. This sector is understood by researchers as an element of national economy based on intellectual ownership originating from culture and science [12], [20]. The researchers of the creative sector most frequently invoke the elaborations of the Department of Media, Culture and Sport (DCMS) in British Government. According to the elaborations, creative activities encompass these ones based on human creativity, talent and skills, as well as creating and utilizing intellectual property, and incorporate the potential of forming prosperity and contribute the formation of new workplaces. According to the Department of Media, Culture and Sport, they include: advertising, publishing, photography, architecture, the market of arts and antiques, radio, television, film, video, music, design (graphic, interior, industrial, multimedia, fashion), artistic and entertainment activities, artistic craftsmanship, activities related to software, as well as computer and video games [17].

Nevertheless, in the literature of the subject a discourse appeared on the necessary factors stimulating the presence and development of creative activities in cities. According to Ch. Landry [13], they are different forms of city life related to human capital and cultural capital of a city to a high degree. Fundamentally, these features are: talented human resources, urban leadership, social diversity, local identity and the organizational culture of a city. Among many factors not related to society, which may be at the utmost of a supplementary character, he indicates space and infrastructure. In turn, B. Namyślak [17] points to a necessity of presence of the following: creative activity, creative society easily adapting to changes in the surroundings, technological infrastructure giving strategic advantage over other urban units, as well as the adequate quality of urban space attracting new inhabitants and investors. Having the diversity of each cities in Poland, Europe and the world in mind, it ought to be remembered that it is a feature distinguishing a given city according to the concept of D. F. Batten [1]. In his opinion, the diversity of phenomena in many layers (private vocational, entertaining, recreational, etc.) evokes the states of artistic intensity, which leads to the creativity of city dwellers. According to D. F. Batten, this "diversity" is fundamentally the only significant indicator of creative cities. The analysis of creative services and activities in Europe indicates that they play a major role in the development and enrichment of regions [5]. They gain a competitive edge at the same time [10], [11]. Creative sector is come European cities encompasses 9-11\% of the workforce [3]. Creative people in socio-economic life of a city are broadly and exhaustively discussed by R. Florida in the book entitled Cities and the creative class (2005) . With the United States of America serving as an example, he proves that a high participation of the creative class formed by well-educated, creative people interested in the participation in cultural events and innovations is characteristic for metropolises. His Bohemian Index based on selected professions highlights the following: authors, designers, composers and musicians, actors and directors, painters, craftsmen, sculptors, graphic designers, photographers, dancers, artists, performers and other related people. Creativity related to culture focuses both on the various institutions of culture, as well as spaces gathering artists. Relations between artistic centres and creative activities are the basis for innovative economic activities. On the other hand, P. Hall and K. Pain [8] incorporate creative and cultural industry: creating art (theatres, operas, ballet, concerts), museums, galleries, print houses and electronic media, into one of the groups of advanced service activities. 
Creativity is one essential element of the development of metropolitan functions, particularly in a city like Katowice which underwent deep and profound restructuring [21], [4], where an essential shift of functions towards the development of services occurred [19]. 43 thousand people in relation to 353 thousand in Poland [7], worked in this sector in 2011 in Silesia, whereas 13.3 thousand companies were related with the creative services sector. Silesia occupies the sixth place in Poland in this matter. The majority (54\%) of business entities defined as creative expanded slightly over the boundaries of 13 cities of the Górnośląsko-Zagłębiowska metropolis. The companies and the creative labour market focus on the most important cities, mainly the core ones. Among the total of 7.1 business entities, most of them are related to advertising (3.7 thousand), architecture (1.9 thousand), institutions of culture and creators (1.9 thousand) and publishing [7].

\section{CREATIV KATOWICE}

The challenges of creativity are being contested by Katowice which initiated new investments on old foundations. Culture Zone was established several years ago. It is a perfect example of the succession of the function of area in the centre of Katowice. Devastated area formerly occupied by "Katowice" coal mine was intended for a megaproject of a metropolitan scale. The mining function was replaced with high-order ones cultural, service-based, exhibition-related, business and catering. In the vicinity of "Spodek" Sport and Event Hall, modern cultural and business space was established, embracing three large objects and metropolitan institutions: National Symphonic Orchestra of Polish Radio (Figure 2), International Congress Centre (Figure 3) and Silesian Museum (Figure 4).

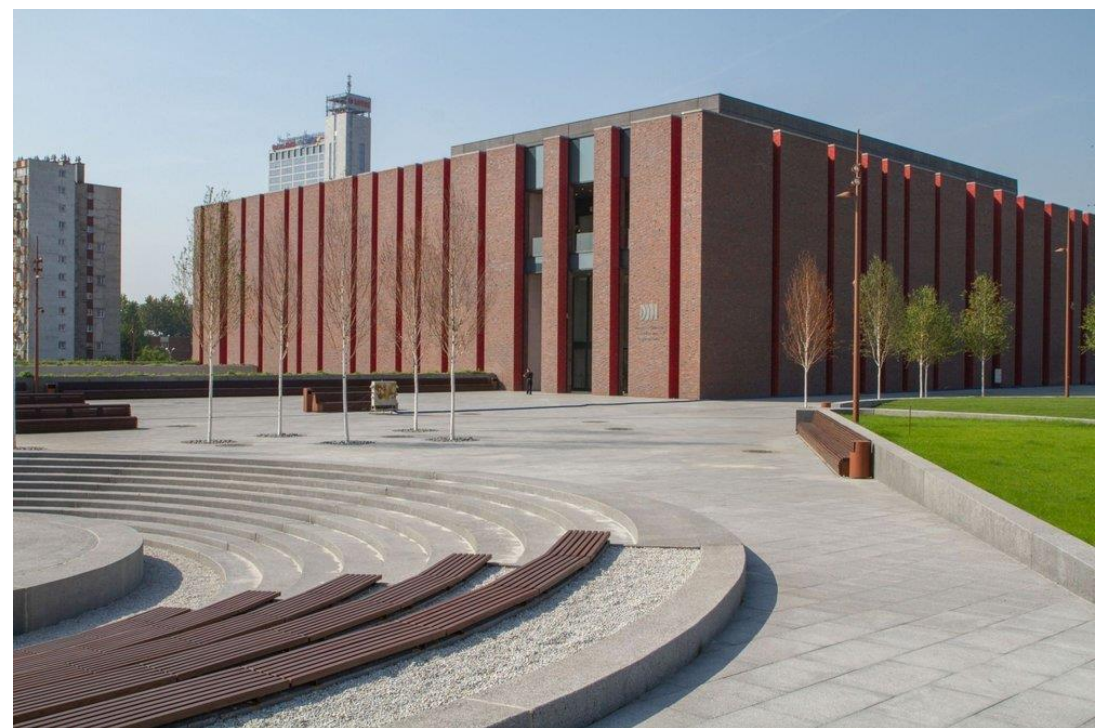

Figure 2. Building of the National Symphonic Orchestra of Polish Radio in Katowice Source: http://panoramasilesia.pl/news/19663/budynek-nospr-idealna-promocja-dla-miasta-i-regionu 


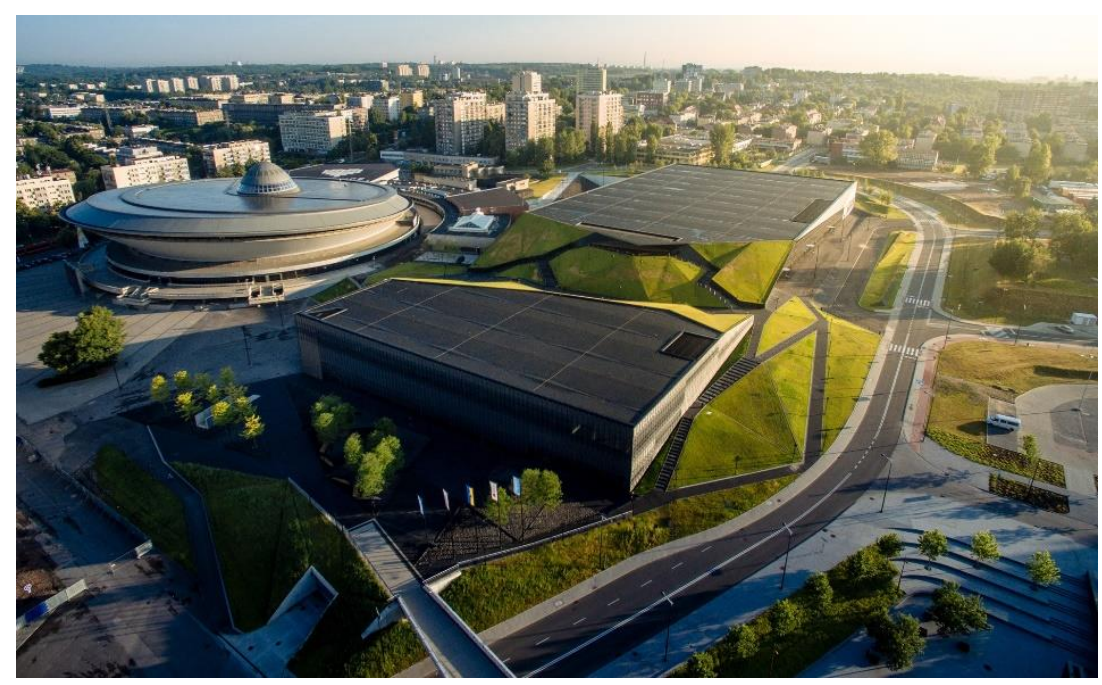

Figure 3. International Congress Centre in Katowice

Source:http://www.urbanity.pl/slaskie/katowice/miedzynarodowe-centrum-kongresowe,b2963

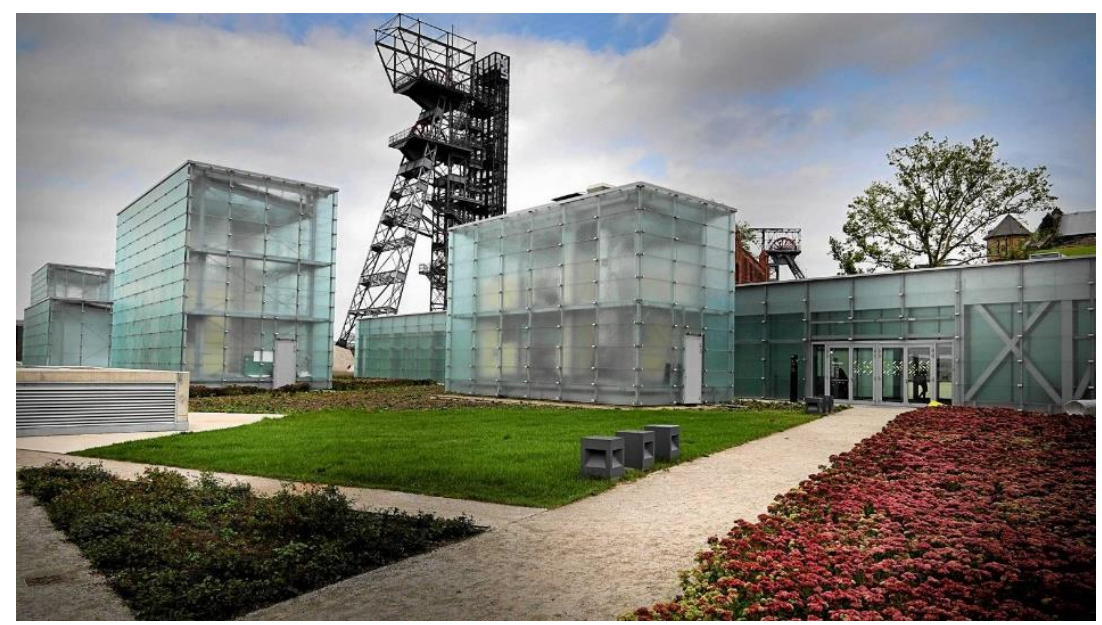

Figure 4. Silesian Museum in Katowice

Source:http://katowice.wyborcza.pl/katowice/7,35018,21784403,muzealne-oscary-rozdane-wyroznieniedla-muzeum-slaskiego.html

These architectonic objects are awarded for creative projects of interesting designs, but even more importantly, there are a basis for the development of the new function of culture, including music. The total value of investment projects, including the rearrangement of the road system, exceeds PLN 1 billion (EUR 237,959,261.00). The fulfilment of the aforementioned could be completed thanks to European funds. Katowice is a location where PLN 1.5 billion worth of investment is in progress (EUR 356,938,892.00). Former minister Bogdan Zdrojewski, during an assessment on the level and quality of the investments in progress, as well as planned cultural events, underscored that Katowice "took a huge leap in terms of quality in relation to attitude towards culture". "Katowice faces three momentous years (...). It is the time which will alter the image of Katowice in an ultimate manner from the point of view of perceiving not only Silesia and Poland, but Europe". Culture Zone was also under the patronage of the Ministry of Culture and now is the flag image project in the region.

The impulse to erect the new building of the National Symphonic Orchestra of Polish Radio was given by Krzysztof Penderecki. He convinced other members of the council - 
Wojciech Kilar and Henryk Mikołaj Górecki, as well as the former president of Katowice Piotr Uszok.

During the inaugurating concert of October 2014, the National Symphonic Orchestra of Polish Radio was accompanied by Krystian Zimerman, a brilliant pianist who has been connected with Katowice since the seventies of the $20^{\text {th }}$ century.

Within the administrative limits of the city, according to the data of General Statistics Office, in 2016 there were 26 units associated within the so-called cultural centres, 13 out of which were private. Cultural activities were carried out by 133 artistic groups, $51.1 \%$ of which were dance groups. In 2011-2016, the cultural centres organized the total of 17,405 different types of events. It shall be highlighted that the number of events organized has been increasing (Figure 5).

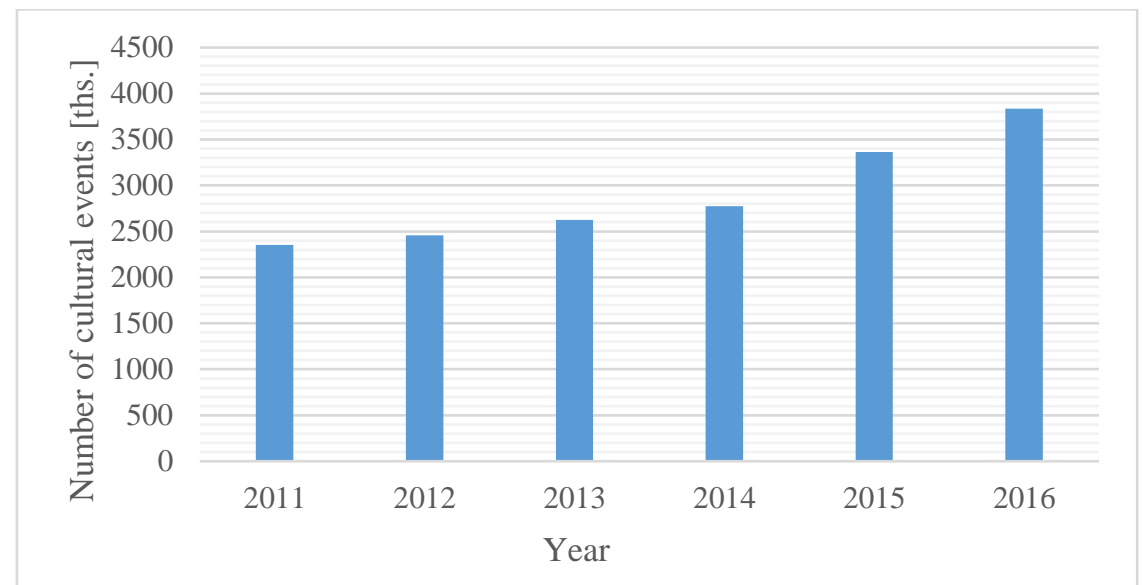

Figure 5. Cultural events organized by cultural centres in Katowice in 2011-2016

Source: author's elaboration on the basis of GUS (General Statistics Office).

The events organized by cultural centres attracted a big number of spectators. On average, each organized event attracted 110 viewers. Nonetheless, it ought to be highlighted that a big proportion of local events attract a smaller number of spectators, in relation to mass events organized in the city. Of the most interesting character in the recent two years were exhibitions and concerts. The Choir of Katowice and the Concert Hall of Silesia named after Henryk Mikołaj Górecki, as well as the National Symphonic Orchestra of Polish Radio function in the city. These institutions organized in 2011-2016 the total of 1,167 events, $69 \%$ of which were in the field of domain of the National Symphonic Orchestra of Polish Radio. Creative activities mentioned in the three units of higher-order culture attracted the total of 787,019 people. This translates into 363 spectators on each organized cultural event. However, the dominant role of the National Symphonic Orchestra of Polish Radio shall be highlighted here. It attracted over seven times more spectators in relation to 2011 (Table 1).

Table 1. Number of participants of events organized by cultural units in Katowice in 2011-2016

\begin{tabular}{|c|c|c|c|c|c|c|}
\hline Cultural Institutions & $\mathbf{2 0 1 1}$ & $\mathbf{2 0 1 2}$ & $\mathbf{2 0 1 3}$ & $\mathbf{2 0 1 4}$ & $\mathbf{2 0 1 5}$ & $\mathbf{2 0 1 6}$ \\
\hline Katowice Choir & 400 & 190 & 700 & 500 & 310 & 445 \\
\hline Silesian Philharmonic & 18251 & 15302 & 0 & 33461 & 47462 & 49073 \\
\hline $\begin{array}{c}\text { Polish National Radio } \\
\text { Symphony Orchestra }\end{array}$ & 34523 & 29822 & 36453 & 77207 & 205578 & 237342 \\
\hline Total & $\mathbf{5 3 1 7 4}$ & $\mathbf{4 5 3 1 4}$ & $\mathbf{3 7} \mathbf{1 5 3}$ & $\mathbf{1 1 1} \mathbf{1 6 8}$ & $\mathbf{2 5 3 3 5 0}$ & $\mathbf{2 8 6 ~ 8 6 0}$ \\
\hline
\end{tabular}

Source: author's elaboration. 
As results from field studies and the analysis of potential, both Silesia and Katowice have certain values favouring the development of music. In particular, they concern welldeveloped cultural activities in terms of music, in particular numerous festivals, perceived as promotion through culture. The cultural potential of the city attracts artists and receivers, numerous events stimulate cultural activities and participants, as well as attract artists. The studies suggest that the Academy of Music plays a major role in the creation of music culture and environment in the region. This example confirms the role of the institutions of higher education in the formation of the "creative class" and the development of the region based on culture. Renowned music institutions, apart from the National Symphonic Orchestra of Polish Radio, the Concert Hall of Silesia and the Academy of Music named after Karol Szymanowski, include: "Camerata Silesia" Katowice Music Band, Polish Association of Choirs and Orchestras, Polish Radio Katowice (with Concert Hall), "Silesia" Music Promotion Institution, two Primary and Secondary National Music Schools, National General Primary Music School, ROE Private Artistic Higher Music School and Private School of Popular Music NICE NOISE. These institutions organize music events of a nationwide and international character (Table 2). DO ZASTANOWIENIA, CZY TEGO NIE USUNĄC

Table 2. Music events of nationwide and international character in Katowice

\begin{tabular}{|l|l|}
\hline $\mathbf{N}^{\mathbf{0}}$ & \multicolumn{1}{c|}{ Music Event } \\
\hline 1 & International Competition for Conductors of Grzegorz Fitelberg \\
\hline 2 & Vocal Music Days \\
\hline 3 & International Festival for Young Laureates of Music Competitions \\
\hline 4 & International Summer Music Festival: "Chamber and Organ” \\
\hline 5 & TAURON New Music Festival \\
\hline 6 & Rawa Blues Festival \\
\hline 7 & Festival of Chamber Music: "Ars Cameralis" \\
\hline 8 & Off Festival \\
\hline 10 & Katowice JazzArt Festival \\
\hline 11 & Festival of Improvised Music: "jaZZ \& Beyond” \\
\hline 12 & International Festival of Choral Song: "Trojok Śląski” \\
\hline 13 & World Music Festival: "Gardens of Sounds" \\
\hline 14 & Katowice Music Days of Henryk Mikołaj Górecki \\
\hline 15 & Silesian Days of Contemporary Music \\
\hline 16 & International Cello Festival \\
\hline 17 & Promenade concerts: "From Bach to Beatles” \\
\hline 18 & Mayday \\
\hline 19 & Let's meet on Mariacka street \\
\hline 20 & $\begin{array}{l}\text { Concerts: Polish National Radio Symphony Orchestra, Silesian Philharmonic (Symphony } \\
\text { Orchestra and Choir SP), Silesian Quartet, Camerata Silesia Singers' Ensemble Katowice, } \\
\text { as well as music events at Katowice Cultural Centre of K. Bochenek, in Concert Hall of the } \\
\text { Music Academy of K. Szymanowski, in Silesian Library }\end{array}$ \\
\hline
\end{tabular}

Source: author's elaboration.

Mariacka street plays a major role in music and artistic life of the city. It was revitalized several years ago in order to enliven the area and establish a new function related to culture and entertainment. Of significant importance are also numerous clubs, cafés and student clubs.

The total of 6.5 thousand mass events are organized yearly in Poland. In 2016, 24.4 million participants took part in these events, which translates into 3.8 thousand people per one event (Mass events, 2017). Out of which, as much as $48.6 \%$ are art and 
entertainment events (3.1 thousand; $49.7 \%$ are sport events). They encompass, inter alia, concerts $(1,547-23.8 \%$ in Poland), festivals $(234-3.6 \%)$ and other events $(1,378$ mass events of various types, such as comedy shows, combined events, live shows and other events).

In Silesia, where Katowice is located, the total of 817 mass events took place in 2016. This figure is the highest in Poland. 3.6 million participants took part in the events $(14.7 \%$ in Poland).

What is more, there are 20 theatres and music institutions in Silesia, such as: philharmonics, operas, operettas - music theatres, orchestras, choirs, dance groups. Music spectacles and concerts take place there. The most popular theatres was a drama theatre and a puppet theatre which - in the period of 6 years - played the total of 3,821 different spectacles for 503,561 people. The highest number of music institutions is in Katowice, however - due to the complex functional-spatial arrangement of GórnośląskoZagłębiowska Metropolis which transforms into a metropolitan area - cultural institutions are dispersed.

Students and graduates of universities, institutes of technology, art schools, Academy of Fine Arts and Academy of Music, as well as the departments of architecture, human sciences, IT, radio and television are, among the others, future establishers of the creative labour market. Currently the creative class in Katowice is formed by 1,393 professional artists, including over 300 composers, artists and related creators, choreographers and dancers [16].

\section{SUMMARY}

Creative city is considered a city with an ability to generate and introduce new ideas, projects, innovations, as well as an ability to attract and retain creative individuals and business entities from the creative sector. The analysis of cultural events in the period of six years confirms that Katowice meets these requirements. Within city limits there are activities carried out by the people of the creative class. It is possible thanks to space where certain infrastructure being an attractive living and working place for creative people was established. Judging from the perspective of creativity as a significant element for the development of metropolitan functions, all business entities specified as creative strengthen the process of metropolization. The culture and cultural policy of Katowice is currently in a critical moment. Katowice has effectively and swiftly changed its image from an industrial city to a "city of gardens". Currently, on the areas of original industrial functions, areas of culture related to post-industrial tourism or culture of higher order primarily music - have appeared. Thanks to the aforementioned, on 11 December 2015 Katowice was awarded with the title of UNESCO Creative City in the field of music. The world-renowned brand of a creative city guarantees an increase of significance of a city worldwide, being a quality mark attracting people, as well as an additional impulse for the development of local economy. Awarding this prestigious title, UNESCO appreciated and acknowledged the diversity of potential of the city in terms of music. Katowice is proud of its renowned festivals of classical music, alternative and electronic music, the activities of the National Symphonic Orchestra of Polish Radio, as well as the work of famous artists - Henryk Mikołaj Górecki and Wojciech Kilar (both are composers). The membership of Katowice in the Network of Creative Cities which encompasses 116 cities, including but not limited to: Bogota (Colombia), Seville (Spain), Bologna (Italy) or 
Glasgow (Great Britain) allows the cooperation between cities in organizing joint ventures in terms of musical creativity.

\section{REFERENCES}

[1] Batten D. F., Network Cities: Creative Urban Agglomerations for the 21st Century. Urban Studies 32/2, pp 313-327, 1995.

[2] Blotevogel H., Metropolregionen [in:] Akademie fur Raumforschung und Landespanung [red.] Handworterbuch der Raumordnung, Hannover, pp 642-647, 2004.

[3] Boix R., Propis L., Lazzeretti L., Sanchez D., Capone F., The geography of creative industries in Europe: Comparing France, Grat Britain, Italy and Spain, International Meeting on Regional Science, The future of the cohesion policy, Badajoz-Elvas, 2010.

[4] Chmielewska M., Lamparska M., Post-industrial tourism as a chance to develop cities in traditional industrial regions in Europe, [w:] Revista Sociologie Românească, vol. X, pp 67-75, 2012.

[5] De-Migeuel-Molina B., Hervas-OliverJ-L., Boix R., De-Miguel-MolinaM., The importance of Creative industry Agglomerations in Explaining the Wealth of Europen Regions, Europen Planning Studies, t. 20, no 8, pp 1263-1280.

[6] Florida R., Cities and the Creative Class, New York, 2005.

[7] Funkcje Metropolitalne, Urząd Marszałkowski Województwa Śląskiego, Poland, 2012.

[8] Hall P., Pain K., The Polycentric Metropolis: Learning from Mega-City Regions in Europe, Earthscan, London, 2006.

[9] Jałowiecki B., Szczepański M., Miasto i przestrzeń w perspektywie socjologicznej, Poland, 2006.

[10] Klasik A., Aktywność przedsiębiorcza I konkurencyjność ekonomiczna miast w procesie restrukturyzacji aglomeracji miejskich, Polnad, 2008.

[11] Klasik A., Rola sektora kultury i przemysłów kreatywnych w rozwoju miast i aglomeracji, Poland, 2010.

[12] Klasik A., The Culture Sector and Creative Industries as a New Foundation of Development of Large Cities and Urban Agglomerations. W: A. Klasik red., The Cities and Agglomerations Development based on the Culture Sector and Creative Industries. Studia Regionalia 30, Polish Academy of Science,, pp 14-41, Poland, 2011.

[13] Landry Ch., The Creative City. A Toolkit for Urban Innovators, Earthscan, London 2008.

[14] Liszewski M., Maik W., Osadnictwo, Wielka Encyklopedia Geografii Świata, Poland, t.19, 2000.

[15] Markowski T., Marszał T., Metropolie. Obszary metropolitalne. Metropolizacja. Problemy i pojęcia podstawowe, KPZK PAN, Poland, 2006.

[16] Murzyn-Kupisz M., Działek J., Artyści w przestrzeni miejskiej Krakowa i Katowic, UNIVERSITAS, Kraków, 2017.

[17] Namyślak B., Działalności twórcze a rozwój miast. Przykład Wrocławia. Rozprawy Naukowe Instytutu Geografii i Rozwoju Regionalnego Uniwersytetu Wrocławskiego 30, Uniwersytet Wrocławski, Wrocław, Poland 2013.

[18] Parysek J., Metropolie: metropolitalne funkcje i struktury przestrzenne, [red.] Jażdżewska I., Funkcje metropolitalne i ich rola w organizacji przestrzeni, XVI Konwersatorium wiedzy o mieście, Poland, pp19-40, 2003.

[19] Raźniak P., Dorocki S., Winiarczyk-Raźniak A., Eastern European cities as command and control centres in a time of economic crisis, Acta Geographica Slovenica, 58, 2, pp 101-110. 
[20] Stryjakiewicz T., Stachowiak K., Sektor kreatywny w poznańskim obszarze metropolitalnym, tom 1: Uwarunkowania, poziom i dynamika rozwoju sektora kreatywnego w poznańskim obszarze metropolitalnym., Poland, 2010.

[21] Tkocz M., Riley R. Local Respones to Changed Circumstances: Coalmining in Upper Silesia, Geojournal, 48, pp 279-290, 1999.

[22] Zöpel Ch., Zagłębie Ruchry I Górny Śląsk w sieci metropolii europejskich. Aglomeracje przemysłowej jako metropolitalne obszary miejskie, Dom współpracy Polsko-Niemieckiej, Fundacja im. Fredricha Eberta, Poland, 2011.

[23] Zuzańska-Żyśko E., Procesy metropolizacji. Teoria i praktyka, Poland, 2016. 